\title{
Utilization of IncP-1 Plasmids as Vectors for Transposon Mutagenesis in Myxobacteria
}

\author{
By PATRICK SAULNIER, ${ }^{1}$ JOSE HANQUIER, ${ }^{1}$ SAMIR JAOUA, ${ }^{2}$ \\ HANS REICHENBACH ${ }^{3}$ AND JANINE F. GUESPIN-MICHEL ${ }^{2 *}$ \\ ${ }^{1}$ Laboratoire de Génétique Microbienne, Université de Technologie de Compiègne, BP 233, \\ F-60206 Compiègne, France \\ ${ }^{2}$ Laboratoire de Microbiologie, Université de Rouen, Faculté des Sciences et Techniques, BP 118 , \\ F-76134 Mont-Saint-Aignan Cedex, France \\ ${ }^{3}$ Gesellschaft für Biotechnologische Forschung, Mascheroder Weg 1, D-3300 Braunschweig, FRG
}

(Received 19 May 1988)

\begin{abstract}
No free plasmid has ever been found in the myxobacterium Myxococcus xanthus, but IncP-1 plasmids are able to integrate into the chromosome of this bacterium. The frequency of integration depends greatly upon the structure of the IncP-1 plasmid used. This property has been used to devise new delivery systems for transposon mutagenesis in this species. Plasmids with low integration efficiencies have proved to be efficient donors of $\mathrm{Tn} 5$, while plasmids with very high frequencies of integration could be used directly to generate mutations. These vectors have also proved efficient for Tn5 transfer into other species of myxobacteria, which have not so far been susceptible to genetic analysis.
\end{abstract}

\section{INTRODUCTION}

The myxobacterium Myxococcus xanthus is a very peculiar Gram-negative bacterium. Its numerous unusual properties have interested biologists who study morphogenesis (Kaiser et al., 1979), gliding motility (Hodgkin \& Kaiser, 1979) and protein secretion (Nicaud et al., 1984), as well as biotechnologists who try to use it for antibiotic or protein production (Breton et al., 1984; Gerth et al., 1983; Rosenberg et al., 1984).

Genetic studies of this species started with the discovery of generalized transducing phages (Campos et al., 1978). Later it was found that the coliphage P1 can adsorb and inject its DNA into, but cannot develop in $M$. xanthus (Kaiser \& Dworkin, 1975). It was later shown that coliphage P1 allows the transfer of transposon Tn5, which then integrates randomly into the chromosome, generating mutations (Kuner \& Kaiser, 1981). More recently this vector has been successfully utilized to transfer $M$. xanthus genes that had been cloned in Escherichia coli back into the original host (Shimkets et al., 1983). Only a few strains of M. xanthus are, however, susceptible to genetic analysis, although several other strains or species have proved to be of interest, with regard to antibiotic production (Reichenbach et al., 1988) or morphogenesis (Kaiser et al., 1979).

The broad-host-range plasmid RP4 can be transferred by conjugation from $E$. coli to $M$. xanthus, where it is maintained integrated in the chromosome (Breton et al., 1985). The efficiency of the transfer depends on both the recipient strain and the structure of the RP4 derivative used (Jaoua et al., 1987). In some instances it can reach values of $10^{-1}$.

We describe here the use of RP4 derivatives to promote efficient transfer and, consequently, transposition of $\operatorname{Tn} 5$ into characterized strains of $M$. xanthus, as well as into other strains of the same or other species (Myxococcus fulvus and Myxococcus stipitatus). 


\section{METHODS}

Bacterial strains and culture conditions. Bacterial strains and plasmids used are listed in Table 1.

All three Myxococcus species were grown at $30^{\circ} \mathrm{C}$ in CYE medium (Zusman et al., 1978). Myxococcus fulvus was additionally plated on MXF medium: Casitone (Difco) $0.5 \% ; \mathrm{CaCl}_{2}, 0.05 \% ; \mathrm{MgSO}_{4} .7 \mathrm{H}_{2} \mathrm{O}, 0.05 \% ; \mathrm{pH} 7.2$ (K. Gerth, personal communication). E. coli was grown at $37^{\circ} \mathrm{C}$ in L broth (Miller, 1972).

These media were solidified with $1.2 \%$ agar (Biomerieux). Milk plates were prepared from CYE plates overlaid with $3 \mathrm{ml}$ of a $2: 1$ mixture of soft agar $(0.6 \%)$ and sterilized skimmed milk. Proteolytic activity was estimated by the size of the lysis halo surrounding colonies toothpicked onto CYE milk plates, as compared to that of control strains. Proteolytic activity and total protein were assayed in the supernatant of liquid cultures as described before (Nicaud et al., 1984).

The antibiotics used and their final concentrations $\left(\mathrm{mg} \mathrm{l}^{-1}\right)$ were: for myxobacteria, kanamycin sulphate (Kan), 75 or 50 (Bristol Laboratories); oxytetracycline chlorohydrate (Otc; used to select strains of Myxococcus harbouring a tet gene), 12.5 (Roussel Uclaf); and streptomycin sulphate (Str) 500 (Diamant); for E. coli, nalidixic acid (Nal), 100; tetracycline (Tet), 10 (Roussel-Uclaf); and phleomycin (Phl), 5 (Civea).

Matings. These were done as described by Breton et al. (1985). The donor strains were counterselected with streptomycin. Transfer frequencies are reported as the number of transconjugants per recipient cell.

Plasmid extraction and detection. Plasmids were extracted from E. coli by the clear-lysate technique (Cohen \& Miller, 1969) and the supercoiled plasmid DNA was separated from linear chromosomal DNA by ultracentrifugation in a $\mathrm{CsCl} /$ ethidium bromide gradient (Clewell \& Helinski, 1969). Free supercoiled plasmid DNA was visualized in agarose gels after in situ lysis (Eckhardt, 1978).

Preparation of DNA and Southern blot hybridization. The blot hybridization method of Southern (1975) was used to determine the size of $M$. xanthus chromosomal DNA fragments displaying homology with either $\operatorname{Tn} 5$ or pME305. Chromosomal DNA was extracted as described by Breton et al. (1985); $5 \mu$ gNA was digested with a restriction enzyme ( $\mathrm{Sal}$ I or Pst I) as described by the supplier (Boehringer-Mannheim and Appligen, respectively). $\lambda$ DNA digested with EcoRI and HindIII (Boehringer Mannheim) was used as a standard.

The plasmid DNA to be used as a probe was labelled by nick-translation, using $2 \mathrm{mCi}$ (74 MBq) $\left[\alpha-{ }^{32} \mathrm{P}\right] \mathrm{dCTP}$ (Amersham) $\mathrm{ml}^{-1}$ and $200 \mathrm{ng}$ DNA in $25 \mu \mathrm{l}$ volumes incubated at $15^{\circ} \mathrm{C}$. Hybridization of the labelled probe to the chromosomal DNA fragments attached to nitrocellulose was done as described by Breton et al. (1985).

Construction, preparation and isolation of an RP4::Tn5 plasmid. Phage $\lambda$ NK467 was used to transfer Tn 5 to a culture of $E$. coli W3101 Nal(RP4). Tn5 transposition was monitored by the acquisition of resistance to bleomycin/phleomycin (Mazodier et al., 1985). The RP4::Tn5 plasmids were selected after mating $E$. coli W3101 Rif recipients with the pool of $\mathrm{Bl}^{\mathrm{r}}$ transduced cells, as $\mathrm{Bl}^{\mathrm{r}} \mathrm{Oc}^{\mathrm{r}}$ transconjugants. One RP4 : :Tn 5 plasmid was purified, after checking that no loss in transferability had occurred, and that its size was as expected.

\section{RESULTS}

\section{Transposition of Tn5 in M. xanthus}

We have studied the transposition of Tn 5 carried by plasmid pME462, which had been shown previously to integrate with a low frequency into the $M$. xanthus chromosome (Jaoua et al., 1987). Two recipient strains were used: DZ1, which is a good conjugal recipient of RP4, and CM207, which is a rather poor recipient (Breton et al., 1985).

In both instances, only two classes of transconjugants were obtained (Table 2). The majority were $\mathrm{Km}^{\mathrm{r}}$ only $(98 \%$ of the CM207 transconjugants and $92 \%$ of the DZ1 transconjugants) whereas a minority also expressed $\mathrm{Oc}^{\mathrm{r}}$, which, like $\mathrm{Km}^{\mathrm{r}}$, is encoded by pME462. Increasing the transfer frequency by using an intermediate, non-selected $E$. coli host (tri-parental cross) did not modify these ratios (Table 2 ).

To check whether the $\mathrm{Km}^{\mathrm{r}} \mathrm{Oc}^{\mathrm{r}}$ transconjugants carried an integrated pME462 in their chromosome, we demonstrated the ability of six randomly chosen transconjugants of this class to retransfer the plasmid to $E$. coli. Then total DNA from one of the transconjugants was digested with $P s t \mathrm{I}$ and probed with radioactive pME305 DNA. Hybridization showed that the entire plasmid was present (data not shown).

$\mathrm{Km}^{\mathrm{r}} \mathrm{Oc}^{\mathrm{s}}$ transconjugants, however, could result either from $\mathrm{Tn} 5$ transposition into the chromosome of a bacterium in which the plasmid had not been integrated, or from a deletion of part of an inserted pME462 (Jaoua et al., 1986). When the DNA from four randomly chosen transconjugants was probed with radioactive pME305 DNA, no hybridization was detected (results not shown). However a dot-blot analysis of a pool of transconjugants of this class with 
Table 1. Bacterial strains and plasmids

Strain

Myxococcus xanthus

DK101

DZ1

CM207

$\mathrm{Mxx} 12$

CM500

Myxococcus fulvus

Mxf 16

CM700

Myxococcus stipitatus

Mxs1

Mxs2

CM800

CM850

E. coli

W3101 Nal

W3101 Rif

C600

IncP-1 plasmids

RP4

pME305

pME462

pUZ8

RP4::Tn5

pCM2019

pCM2023

Other plasmids

ColE1 : : Tn5

Phage

$\lambda$ NK 467
Relevant characteristics*

Reference wild-type

Str ${ }^{\mathrm{r}}$

Str $^{\mathrm{r}}$ mutant of DK101

Natural isolate; Str $^{\mathrm{s}}$

$\mathrm{Str}^{\mathrm{r}}$ mutant from $\mathrm{Mxx} 12$

Myxothiazol-producing strain

Str ${ }^{r}$ mutant from Mxfl6

Natural isolate

Natural isolate

$\mathrm{Str}^{r}$ mutant of Mxs1

Str $^{\mathrm{r}}$ mutant of Mxs2

recA13 trpE Nalr

recA13 trpE Rif

thi-1 thr-1 leuB6 lac Y1

tonA21 supE44

$\mathrm{Km} \mathrm{Tc/Oc} \mathrm{Ap}$

Tc/Oc Ap rep ${ }^{\text {ts }}$

Tc/Oc Ap rep ${ }^{\text {ts }} \mathrm{Km} \mathrm{Bl}$

(pME305::Tn5)

$\mathrm{Km} \mathrm{Tc/Oc} \mathrm{Hg}$

$\mathrm{Km} \mathrm{Tc/Oc} \mathrm{Ap} \mathrm{B1}$

$\mathrm{Km} \mathrm{Tc} / \mathrm{Oc} \mathrm{Hg}$

$\mathrm{Km} \mathrm{Tc/Oc} \mathrm{Ap}$

Km Bl rep ${ }^{\text {ts }}$

b221 rex: : $\operatorname{Tn} 5$ cI857

O29am P80am
Source or reference

Hodgkin \& Kaiser (1979)

Zusman et al. (1978)

Breton et al. (1985)

Gerth et al. (1983)

This work

Gerth et al. (1980)

This work

Provided by Dr Reichenbach,

GBF, Braunschweig, FRG

This work

This work

Kopecko et al. (1976)

Kopecko et al. (1976)

Appleyard (1954)

M. Rella via J. Brevet, Université

Paris XI, Orsay, France

Rella (1984)

Rella (1984)

Hedges \& Matthew (1979)

This work

Jaoua et al. (1986)

Jaoua et al. (1987)

Gift from C. Elmerich,

Institut Pasteur, Paris, France

N. Kleckner via J. P. Bohin, Université Paris XI, Orsay, France

* $\mathrm{Km}, \mathrm{Tc} / \mathrm{Oc}, \mathrm{Ap}$ and $\mathrm{Bl}$ (resistance to bleomycin/phleomycin) are plasmid markers.

Table 2. Frequencies of transposition and of plasmid integration using different vectors and two recipient strains

The donor strain was $E$. coli $\mathrm{W} 3101(\mathrm{Nal})$ The frequencies represent the number of cells resistant to the corresponding antibiotic per recipient $\operatorname{Str}^{\mathrm{r}}$ Myxococcus cell. In each case 100 colonies from the selection plate were toothpicked on a plate containing the other antibiotic, thus allowing estimation of the percentage of clones displaying only one resistance : $\left(\% \mathrm{Oc}^{\mathrm{s}}\right)$ among the $\mathrm{Km}^{\mathrm{r}}$ cells or $\left(\% \mathrm{Km}^{\mathrm{s}}\right)$ among the Oc cells.

Recipient strain...

Vector

pME462

pME462 with

intermediate host $\dagger$

RP4:: :Tn5

pME305 + ColE1 : :Tn5

pCM2019

$\begin{array}{cc}\overbrace{\mathrm{Km}^{r}\left(\% \mathrm{Oc}^{\mathrm{s}}\right)^{*}}^{\mathrm{DZ1}} & \mathrm{Oc}^{\mathrm{r}\left(\% \mathrm{Km}^{\mathrm{s}}\right)} \\ 5 \times 10^{-4}(92) & 8 \times 10^{-5}(0) \\ 9 \times 10^{-4}(92) & 4.6 \times 10^{-5}(0) \\ & \\ 1.5 \times 10^{-3}(45) & 5.3 \times 10^{-4}(0) \\ 1 \times 10^{-8}(100) & 7.5 \times 10^{-6}(100) \\ 2 \times 10^{-1} & 2 \times 10^{-1}\end{array}$

\begin{tabular}{|c|c|}
\hline \multicolumn{2}{|c|}{ CM207 } \\
\hline $\mathrm{Km}^{\mathrm{r}}\left(\% \mathrm{Oc}^{\mathrm{s}}\right)^{*}$ & $O c^{r}\left(\% \mathrm{Km}^{\mathrm{s}}\right)$ \\
\hline $\begin{array}{r}2 \times 10^{-8}(98) \\
1.3 \times 10^{-7}(95)\end{array}$ & $\begin{array}{c}6 \times 10^{-9}(0) \\
-\end{array}$ \\
\hline $10^{-6}(85)$ & - \\
\hline $1 \times 10^{-3}$ & $1 \times 10^{-3}$ \\
\hline
\end{tabular}

ND, None detected. -, Not done.

* Estimated from 100 toothpicked $\mathrm{Kan}^{\mathrm{r}}$ colonies tested on Otc agar.

$\dagger$ Exponentially growing $E$. coli $\mathrm{C} 600$ cells were added to the conjugation mixture at a concentration equal to that of the donor cells. 


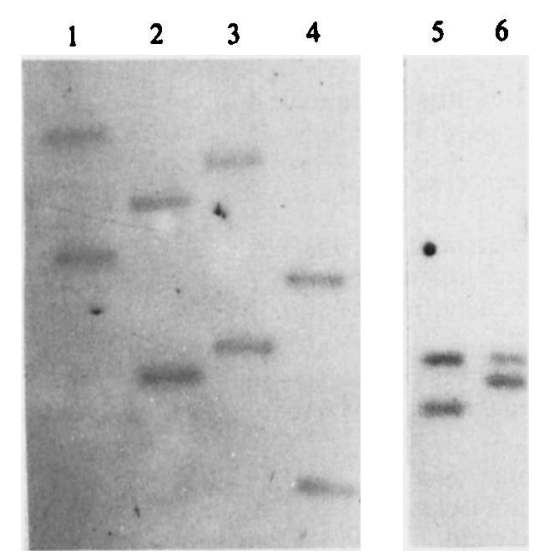

Fig. 1. Autoradiogram of Southern blot hybridization with a ColE1 : :Tn 5 probe. Total genomic DNA from the test strains was digested with $S a l I$ restriction endonuclease and the fragments generated were separated on a $0.7 \%(\mathrm{w} / \mathrm{v})$ agarose gel. The DNA was transferred to nitrocellulose according to Southern (1975) and hybridized with nick-translated ColE1 : :Tn5 probe DNA. Lanes 1 to 4, DZ1 $\left(\mathrm{Km}^{\mathrm{r}} \mathrm{Oc}^{\mathrm{s}}\right)$ DNA [transconjugants from $\mathrm{DZ1} \times \mathrm{W} 3101(\mathrm{pME} 462)$ mating]. Lanes 5 and $6, \mathrm{DZ1}$ $\left(\mathrm{Km}^{\mathrm{r}} \mathrm{Oc}^{\mathrm{s}}\right)$ DNA [transconjugants from DZ1 $\times$ W3101(pME305, ColE1 ::Tn5) mating]

the same probe showed some hybridization. In contrast, when probed with radioactive ColE1 : :Tn5 plasmid, after digestion with SalI, the DNA of these four clones showed two distinct bands. The size of these fragments was different in each case (Fig. 1, lanes 1 to 4), indicating that $\operatorname{Tn} 5$ was inserted at a different site in each instance ( $\mathrm{Tn} 5$ possesses a single SalI site). A phenotypic analysis of 1000 transconjugants from each recipient strain was undertaken. The phenotypic traits scored were chosen so as to permit comparison of the results with those obtained previously with strain DK101 using phage P1 ::Tn5 (Guespin-Michel et al., 1984), according to the method of Kuner \& Kaiser (1981). Table 3 shows that transposon mutagenesis was comparable with both techniques.

Two other vectors were compared for their efficiency of transposition of $\operatorname{Tn} 5$ measured only, in these instances, as the frequency of $\mathrm{Km}^{\mathrm{r}} \mathrm{Oc}^{\mathrm{s}}$ transconjugants. (i) An RP4 : :Tn 5 plasmid was prepared as described in Methods. Its frequency of transfer was higher than that of pME462 with both recipient strains, but the ratio of $\mathrm{Km}^{\mathrm{r}} \mathrm{O} \mathrm{c}^{\mathrm{r}}$ transconjugants to $\mathrm{Km}^{\mathrm{r}} \mathrm{Oc}^{\mathrm{s}}$ transconjugants was also higher - especially with strain DZ1 (Table 2). (ii) We attempted to mobilize the ColE1 : : Tn5 plasmid using pME305 as the conjugative plasmid. No $\mathrm{Km}^{\mathrm{r}} \mathrm{Oc}^{\mathrm{r}}$ transconjugants were obtained, while $\mathrm{Km}^{\mathrm{r} O c^{\mathrm{s}}}$ transconjugants of $\mathrm{DZ1}$ were recovered at low frequency (Table 2).

Two $\mathrm{Km}^{\mathrm{r}} \mathrm{Oc}^{\mathrm{s}}$ transconjugants of $\mathrm{DZl}$ were analysed by Southern hybridization of SalIrestricted total DNA with a radioactive ColE1 $:: \operatorname{Tn} 5$ probe. The results showed that $\operatorname{Tn} 5$ was integrated at a different place in the chromosome in each case (Fig. 1, lanes 5 and 6).

\section{Insertion of pCM2019 in M. xanthus}

Plasmid pCM2019 was obtained after transfer of integrated plasmid pUZ8 in strain DZ1 back to $E$. coli (Jaoua et al., 1987). Its frequency of chromosome integration in $M$. xanthus is very high, even in strain CM207 (Table 2). A total of 2100 transconjugants from strain DZ1 were screened for mutagenesis using the same criteria as were employed for Tn 5 mutagenesis. Table 3 shows that similar rates of mutation were obtained in all cases, suggesting that pCM2019 has several possible insertion sites in the chromosome of this strain.

\section{Tn5 transfer into other myxobacterial strains}

Several myxobacterial strains have been tested as recipients in matings with the abovedescribed E. coli strains. Some of them proved difficult to cultivate under our standard conditions, so we eventually selected four strains belonging to three different species, in order to 
Table 3. Frequency of mutations obtained in $M$. xanthus, using different vectors

The donor strains were $E$. coli $\mathrm{W} 3101 \mathrm{Nal}$ harbouring the different plasmids except when the P1::Tn5 phage lysate was used. Transfer frequencies are estimated as described in Table 2. Mutation frequencies are reported as the number of mutated cells for a given trait, per assayed transposed clone (1000 to 2500 depending on the experiment).

\begin{tabular}{|c|c|c|c|c|}
\hline Recipient strain & DZ1 & CM207 & DK $101^{*}$ & DZ1 \\
\hline Vector & pME462 & pME462 & P1::Tn5 & pCM2019 \\
\hline $\begin{array}{l}\text { Transposition or } \\
\text { transfer frequency }\end{array}$ & $5 \times 10^{-4} \dagger$ & $2 \times 10^{-8} \dagger$ & $2 \times 10^{-8}$ & $2 \times 10^{-1}$ \\
\hline $\begin{array}{l}\text { Frequency of mutati } \\
\text { Mot }^{-} \ddagger \\
\text { Prt§ }^{-}\end{array}$ & $1.1 \times 10^{-2}$ & $\begin{array}{r}8 \times 10^{-3} \\
1.8 \times 10^{-2}\end{array}$ & $\begin{array}{r}1 \times 10^{-3} \\
1.6 \times 10^{-2}\end{array}$ & $0.9 \times 10^{-2}$ \\
\hline $\begin{array}{l}\text { Distribution of Prt } \mathbf{n} \\
\text { Prt }^{ \pm} \\
\text {Prt }^{++} \\
\text {Exc }^{ \pm} \\
\text {Exc }^{++}\end{array}$ & $\begin{array}{l}2 \\
2 \\
1 \\
1\end{array}$ & $\begin{array}{l}0 \\
2 \\
3 \\
3\end{array}$ & $\begin{array}{l}3 \\
0 \\
3 \\
2\end{array}$ & $\begin{array}{l}7 \\
2 \\
4 \\
1\end{array}$ \\
\hline $\begin{array}{l}* \text { Results from } \\
\dagger \text { Estimated as th } \\
\ddagger \text { Mutants comple } \\
\S \text { Frequency of tra } \\
\text { that of the control. } \\
\text { || The Prt mutants } \\
\text { extracellular protein } \\
\text { Exc }{ }^{ \pm} \text {are hyper- or }\end{array}$ & $\begin{array}{l}\text { el et al. }(198 \\
\text { of } \mathrm{Km}^{\mathrm{r}} \mathrm{Oc}^{\mathrm{s}} \\
\mathrm{d} \text { of motility } \\
\text { colonies wh } \\
\text { and purified } \\
\text { Prt } \\
\text { rs of total pr }\end{array}$ & $\begin{array}{l}\text { tected as sn } \\
\text { ilk agar, we } \\
\text { cultures were } \\
\text { yper- or hys } \\
\text { pectively. }\end{array}$ & $\begin{array}{l}\text { ed colonies. } \\
\text { ded by a ha } \\
\text { or both prote } \\
\text { tic strains, } r\end{array}$ & $\begin{array}{l}\text { ent size from } \\
\text { vity and total } \\
\text { y. Exc }\end{array}$ \\
\hline
\end{tabular}

compare the behaviour of the vectors. Spontaneous mutants to streptomycin resistance were selected from each strain, and each was used as a recipient for the mating.

When RP4 : :Tn 5 and pME462 were used as conjugative plasmids, stable $\mathrm{Km}^{\mathrm{r}}$ transconjugants were obtained, but no transconjugants appeared on the Otc plates (Table 4). To check whether this was due to transposition of $\operatorname{Tn} 5$ alone, or to a failure of Otc, as the selective agent, to detect the presence of an integrated IncP-1 plasmid in these strains, we used RP4 and pCM2019 (or pCM2023) as conjugative plasmids. No transconjugants were detected with RP4, whereas pCM2019 or pCM2023 yielded $\mathrm{Km}^{\mathrm{r}}$ and $\mathrm{Oc}^{\mathrm{r}}$ transconjugants with strains CM500, CM800 and CM850. With strain CM700 we obtained some $\mathrm{Km}^{\mathrm{r}}$ transconjugants with $\mathrm{RP} 4$ when MXF medium was used, but we were unable to detect any other resistance conferred on the strain by this plasmid or by pCM2023 (we tested different concentrations of oxytetracycline, tetracycline or carbenicillin). Dot-blot hybridization of the DNA from $24 \mathrm{Km}^{\mathrm{r}}$ transconjugants with radioactive RP4 showed no hybridization in 16 instances (data not shown), suggesting that $2 / 3$ of the transconjugants have genuine $\operatorname{Tn} 5$ transpositions. As with the results obtained with the first $M$. xanthus strains, DZ1 and CM207, no free plasmids were detected in any of the transconjugants analysed.

\section{DISCUSSION}

Our results show that several IncP-1 plasmids may be used as delivery systems for transposon mutagenesis in standard strains of $M$. xanthus, even though these plasmids are not $100 \%$ suicide vectors.

The transposition frequencies obtained depended on the vector and on the recipient strain. With strain DZ1, not only was the frequency of recovery of transconjugants higher than in strain $\mathrm{CM} 207$, but so also was the ratio of integration $\left(\mathrm{Km}^{\mathrm{r}} \mathrm{Oc}^{\mathrm{r}}\right)$ to transposition $\left(\mathrm{Km}^{\mathrm{r}} \mathrm{Oc}^{\mathrm{s}}\right)$ when both RP4 : :Tn 5 and pME462 were used. This suggests that both the frequency of transfer and the frequency of integration of the transferred plasmids were greater in strain DZ1 than in strain CM207.

Plasmid pME462 was less efficiently integrated than RP4 : :Tn5 in both strain DZ1 and strain CM207. This effect has been shown to correspond to the deletion of a site on RP4:: Tn5 for preferential insertion (Jaoua et al., 1987). Thus pME462 can be considered a good 
Table 4. Frequencies of transconjugants obtained using four different Myxococcus strains as recipient

Recipient strain

M. xanthus CM500

M. stipitatus CM800

M. stipitatus CM850

M. fulvus CM700‡

$\quad$ Plasmid
RP4::Tn5
pME462
RP4
pCM2019
(or pCM2023)
RP4::Tn5
pME462
RP4
pCM2019
(or pCM2023) $\dagger$
RP4::Tn5
pME462
RP4
pCM2019
(or pCM2023) $\dagger$
RP4::Tn5
pME462
RP4
pCM2019
(or pCM2023) $\dagger$

Transconjugant frequencies on selective media*

\begin{tabular}{ll}
\multicolumn{1}{c}{ Kan Str } & \multicolumn{1}{c}{ Otc } \\
$1 \times 10^{-7}$ & $<1 \times 10^{-8}$ \\
$<1 \times 10^{-8}$ & $<1 \times 10^{-8}$ \\
$<3 \times 10^{-7}$ & $<3 \times 10^{-7}$ \\
$1.2 \times 10^{-6}$ & $7 \times 10^{-7}$ \\
& \\
$3.2 \times 10^{-7}$ & $<5 \times 10^{-8}$ \\
$6.5 \times 10^{-7}$ & $<5 \times 10^{-8}$ \\
$<3 \times 10^{-8}$ & $<3 \times 10^{-8}$ \\
$5 \times 10^{-7}$ & $5 \times 10^{-7}$ \\
& \\
$1.8 \times 10^{-7}$ & $<1 \times 10^{-7}$ \\
$2.2 \times 10^{-7}$ & $<1 \times 10^{-7}$ \\
$<3 \times 10^{-8}$ & $<3 \times 10^{-7}$ \\
$2 \times 10^{-7}$ & $2 \times 10^{-7}$ \\
& \\
$2 \times 10^{-8}\left(2 \times 10^{-6}\right)$ & $<1 \times 10^{-8}\left(<1 \times 10^{-8}\right)$ \\
$2 \times 10^{-7}\left(5 \times 10^{-6}\right)$ & $<1 \times 10^{-8}\left(<1 \times 10^{-8}\right)$ \\
$<2 \times 10^{-8}\left(9 \times 10^{-8}\right)$ & $<2 \times 10^{-8}\left(<9 \times 10^{-9}\right)$ \\
$<2 \times 10^{-8}\left(7 \times 10^{-4}\right)$ & $<2 \times 10^{-8}\left(<7 \times 10^{-8}\right)$ \\
&
\end{tabular}

* E. coli $\mathrm{W} 3101 \mathrm{Nal}$ was the donor in each case. Frequencies are the means of two or three estimations. In some cases, unstable transconjugants appeared on the Kan Str selection plates, but were not viable when toothpicked on fresh medium; these are not reported here. The concentrations of antibiotics were $\left(\mathrm{mg}^{-1}\right)$ : Kan, 50 or 75 ; Str, 500 ; Otc, 8 or 12.5 . For Kan and Otc the results obtained with both concentrations were identical and are accordingly reported together.

$\dagger$ In some cases pCM2023, which is another high frequency transfer vector with regard to DZ1 and CM207, was used instead of pCM2019. Since the results were similar, they are reported together.

¥ The results in parentheses are those obtained when selective and numeration plates were made with MXF medium.

transposition vector for the two strains studied here. When the frequency of transfer was increased (for instance by using an intermediate, non-selected E. coli host) the ratio of the two integration events did not change, and satisfactory transposition frequencies were obtained, even with strain CM207. The use of pME305 to mobilize plasmid ColE1 : :Tn5 into M. xanthus, although demonstrated, was not efficient. By contrast, pCM2019, which can be considered a high efficiency of integration plasmid in strains DZ1 and CM207, was shown to insert in several sites in the chromosome of strain DZ1, thus generating mutations similar to those obtained with Tn5.

Other myxobacterial strains were used as recipients, and transfer of some of the plasmids to four of them was achieved. Tn 5 transposition occurred in these recipient strains, although at lower frequencies than those obtained for the two standard strains. Thus, gene transfer from $E$. coli has now been achieved with several myxobacterial strains belonging to three different species, which widens the range of genetic studies possible with myxobacteria and encourages the testing of the IncP-1 vectors with other members of this group. The fate of the conjugated plasmids might not be identical in all strains, however. So far, we find that only pCM2019 and pCM2023 are maintained in all four new strains. These plasmids, isolated after retransfer to $E$. coli from the chromosome of strain DZ1 have a modification(s) which confers on them both a high efficiency of integration in strains DZ1 and CM207 and a low, but measurable, efficiency of transfer in the other strains, including strain Mxx12 of $M$. xanthus.

Work is in progress in our laboratory to elucidate both the mechanism of recombination involved during the integration of RP4 into the chromosome of myxobacteria, and the differences displayed by the strains studied with respect to that integration. 
This work was supported by a grant from the 'Etablissement public regional' de Picardie.

\section{REFERENCES}

APPLEYARD, R. K. (1954). Segregation of new lysogenic types during growth of a doubly lysogenic strain derived from Escherichia coli K12. Genetics 39, 440-444.

Breton, A. M., Nicaud, J. M., Younes, G. \& GUESPIN-MICHEL, J. (1984). Myxococcus xanthus, a Gram-negative non-pathogenic bacterium that secretes proteins into the extracellular growth medium, is a potential cloning host for excreted proteins production. In Third European Congress on Biotechnology 3, pp. 441-446. Weinheim: Verlag Chemie.

Breton, A. M., JaOUA, S. \& GUESPIN-Michel, J. (1985). Transfer of plasmid RP4 to Myxococcus xanthus and evidence for its integration into the chromosome. Journal of Bacteriology 161, 523-528.

Campos, J. M., Geiselsoder, J. \& Zusman, D. (1978). isolation of Bacteriophage $\mathrm{Mx4}$, a generalized transducing phage for Myxococcus xanthus. Journal of Molecular Biology 119, 167-178.

Clewell, D. B. \& HelinsKi, D. (1969). Supercoiled circular DNA protein complex in Escherichia coli induced conversion to an open circular DNA form. Proceedings of the National Academy of Sciences of the United States of America 62, 1139-1166.

COHEN, S. N. \& Miller, C. A. (1969). Multiple molecular species of circular R-factor DNA isolated from Escherichia coli. Nature, London 224, 1273-1276.

ECKHARDT, T. (1978). A rapid method for the identification of plasmid deoxyribonucleic acid in bacteria. Plasmid 1, 584-588.

GerTh, K., IRSCHIK, H., REICHENBACH, H. \& TrowitzsCH, W. (1980). Myxothiazol, an antibiotic from Myxococcus fulvus. I. Cultivation, isolation, physio-chemical and biological properties. Journal of Antibiotics 33, 1474-1479.

Gerth, K., Jansen, R., Reifenstahl, G., Hofle, G., IRSCHIK, H., KUNZE, B., REICHENBACH, H. \& THIERBACH, G. (1983). The myxalamids, new antibiotics from Myxococcus xanthus (Myxobacterales). Journal of Antibiotics 36, 1150-1156.

Guespin-Michel, J. F., Breton, A., Nicaud, J. M. \& YounEs, G. (1984). Etude génétique d'une bactérie à Gram négatif non pathogène, excretrice, Myxococcus xanthus. In Génétique des Microorganismes Industriels, pp. 337-341. Edited by $\mathrm{H}$. Heslot. Paris: Société Française de Microbiologie.

HeDGes, R. W. \& MATTHEW, M. (1979). Acquisition by Escherichia coli of plasmid borne $\beta$-lactamases normally confined to Pseudomonas spp. Plasmid 2, 269-278.

HoDGKIN, J. \& KaISER, D. (1979). Genetics of gliding mobility in Myxococcus xanthus (Myxobacterales): genes controlling movement of single cells. Molecular and General Genetics 171, 167-176.

JaOuA, S., Breton, A. M., Younes, G. \& GuespinMicheL, J. F. (1986). Structural instability and stabilization of IncP-1 plasmids integrated into the chromosome of Myxococcus xanthus. Journal of Biotechnology 4, 313-323.

JaOUA, S., GUESPIN-Michel, J. F. \& Breton, A. (1987). Mode of insertion of the broad-host-range plasmid RP4 and its derivates into the chromosome of Myxococcus xanthus. Plasmid 18, 111-119.

KAISER, D. \& DWORKIN, M. (1975). Gene transfer to a myxobacterium by Escherichia coli phage P1. Science 187, 563-564.

Kaiser, D., Manoll, C. \& Dworkin, M. (1979). Myxobacteria: cell interactions, genetics and development. Annual Review of Microbiology 33, 595-639.

KopeCKo, D. J., BREVET, J. \& CoHEN, S. N. (1976). Involvement of multiple translocating DNA segments and recombinational hot-spots in the structural evolution of bacterial plasmids. Journal of Molecular Biology 108, 333-360.

KUNER, J. M. \& KAISER, D. (1981). Introduction of transposon Tn5 into Myxococcus xanthus for analysis of developmental and other non-selectable mutants. Proceedings of the National Academy of Sciences of the United States of America 78, 425-429.

Mazodier, P., Cossart, P., Giraud, F. \& Gaser, F. (1985). Completion of the nucleotide sequence of the central region of $\operatorname{Tn} 5$ confirms the presence of three resistance genes. Nucleic Acids Research 13, 195-205.

MilleR, J. (1972). Experiments in Molecular Genetics. Cold Spring Harbor, NY: Cold Spring Harbor Laboratory.

Nicaud, J. M., Breton, A. M., Younes, G. \& GuesPIN-Michel, J. F. (1984). Mutants of Myxococcus xanthus impaired in protein secretion: an approach to study a secretory mechanism. Applied Microbiology and Biotechnology 20, 344-350.

Reichenbach, H., GerTh, K., Irschix, H., KUnZe, B. \& HoFle, G. (1988). Myxobacteria, a source for new antibiotics. In Biotechnology of Antibiotics, Steroids and Alkaloids of Medical Importance. Edited by $\mathbf{R}$. Vlahov. Weinheim: VCH Verlagsgesellschaft (in the Press).

Rella, M. (1984). Transposon insertion mutagenesis of the Pseudomonas aeruginosa genome. Thesis, Swiss Federal Institute of Technology, Zürich.

Rosenberg, E., Porter, J. M., Nathan, P. N., MANOR, A. \& VARON, M. (1984). Antibiotic TA: an adherent antibiotic. Biotechnology 2, 796-799.

Shimkets, L. J., Gill, R. E. \& KaISER, D. (1983). Developmental cell interactions in Myxococcus xanthus and the spoC locus. Proceedings of the National Academy of Sciences of the United States of America 80, 1406-1410.

SOUTHERN, E. M. (1975). Detection of specific sequences among DNA fragments separated by gel electrophoresis. Journal of Molecular Biology 98, 503-517.

Zusman, D. R., Krotoski, D. M. \& Cumsky, M. (1978). Chromosome replication in Myxococcus xanthus. Journal of Bacteriology 133, 122-129. 